\title{
The Construction and Development of German Digital Education
}

\author{
Lingling Zhou ${ }^{1, *}$ \\ ${ }^{I}$ Department of Foreign Languages, Guizhou University of Commerce, Guiyang, Guizhou 550000, China \\ *Corresponding author. Email: verazhoulingling@qq.com
}

\begin{abstract}
This paper intends to give a profile for the development process of German digital education. Facing the fierce global competition in digital industry and economic, Germany made efforts in developing digital education and carried out various relevant promoting polices, which were published at a fast speed but did not reveal a clear outline. German digital education construction is not well recognized because of its slow developing pace, yet there are several bright spots within its concept, which are worthy for digital education theory research and German studies. With policy analysis methods, this paper investigates the policies and reports of German federal government as well as authoritative institutions in recent years, summarizes the measures for German digital education construction and analyzes its characteristics in the development. German digital education focuses on industrial development and forms a systematic framework. It constantly strengthens digital infrastructure, promotes the research on digital teaching, highlights the capability to use digital technology, and systematically bolster the digital education within the whole society. It represents the characteristics of industry leading, systematicness, openness and sustainability.
\end{abstract}

Keywords: German, German Education, Digital Education

\section{INTRODUCTION}

Germany calls for an overall digital transformation in the whole society [1]. The initiatives "Economy 4.0" and "Industry 4.0" from Germany contribute to promote the digitization of production and services. Since digital economy requires the support of talent education, Germany puts forward the concepts "Work 4.0 (Arbeit 4.0)", "Vocational Education 4.0" and "Education 4.0". Thus, a range of corresponding policies and measures are carried out to improve digital capability of students, workers, preparatory talents and social groups.

Germany has launched a variety polices to improve the digital education. The relevant documents for that were updated quickly but did not reveal a clear blueprint. This paper intends to sort out the documents, reports and survey statistics of German federal government as well as authoritative institutions in recent years, then summarize and analyze the construction and development of Germany digital education, for the reference of the professionals concerned about German digital education.

\section{THE CONCEPT OF "DIGITAL EDUCA-}

\section{TION"}

The concept of "digital education" was formally issued in the document Education Strategy for a Digital Knowledge Society, which was announced by the Federal Ministry of Education and Research (BMBF) in October 2016. "Digital education" refers to the teaching and learning of digital capability as well as teaching and learning by digital media[2]( the integrated competency of professional using digital media and responsible using of that). Digital education also concerns statistic analysis to teaching data and legal education about digitization such as digital patent protection and cyberspace security[2]. The referred "digital capability" indicates the following factors: information searching and evaluating; providing digital content to other users; using digital equipment, understanding the working principle of digital equipment and digital media; Programming, software development and algorithms, as well as network technology and data security; and independent digital learning based on the above[2]".

According to the concept of digital education given above, the "digital education" referred in this paper includes digital education infrastructure, digital education research, digital teaching methods and citizen-oriented digital skill education.

\section{POLICIES, MEASURES AND PROCESS OF DIGITAL EDUCATION IN GERMANY}

From the 1990s to the beginning of this century, "Moodle", "Stud.Ip", "Ilias", Blackboard and other learning management systems were applied in German universities. Teachers can provide students with E-learning materials and set up interactive chat rooms, but it was not widely promoted [3]. Since 2012, Hasso Plattner Institute in Germany has developed "open HPI", a free interactive 
online teaching platform, under the concept of MOOCs and spreading knowledge in the most advanced way

[4]. Meanwhile, policies such as Digital Media in Primary and Secondary Schools were released to call for the promotion and use of digital media in teaching.

However, the digitization of education in German at this time was limited into digital infrastructure and technology using, e.g. fiber broadband, digital media and other audiovisual education. The idea to change teaching structure and teaching methods through digitization has not been formed, and the digital education idea with the system of Web2.0 at the core has not been popular, systematic digital education was not appeared yet.

As time passed, this system evolved gradually. According to the forming and development process, German digital education construction can be divided into three periods: the first period is characterized by the construction of digital economy and digital infrastructure in Germany; the second period represents the forming of systematic guidelines within the education system and figuration of the construction schedule; in the third period, in view of that artificial intelligence and other high-tech technologies became in the ascendant with a technological upgrading and frequent career change, a number of intensified policies for digitization in various education sectors are launched and promoted at a relatively rapid pace.

\subsection{The First Period: Focusing on Digital Infrastructure and Taking Corresponding Measures in Relevant Areas}

As a part of the digital economy construction measures of the federal government, the formal expression of "digital education" began to appear in documents such as Digital Action Agenda 2014-2017 and Digital Strategy 2025, while the two plans focus on digital economy and its infrastructure.

\subsubsection{Promoting digital infrastructure through "Digital Action Agenda 2014-2017”, and proposing fragmentary digital education initiatives.}

Digital Action Agenda 2014-2017 was published by several federal departments together. This plan takes the development of digital economy as the goal, proposes to strengthen digital infrastructure, build digital economy, develop digital vocation, digital life, digital education and research, ensure digital security and promote other aspects. The part of digital education and research is under the responsibility of the German Federal Ministry of Education and Research (BMBF). It calls for the joint efforts of the federation and the states to strengthen digital education media construction, promote the strategy of "digital learning", develop the digital potential in education, leverage the digital skills of citizens, and boost innovation through digitization.
- Digital infrastructure construction took the priority. Digital resources such as online course platform SchulCloud (2016- ), research data platform Open-Access (2016-) and public teaching Resource platform Open Education Resource (2016-) projects were built then.

- Digital skills were promoted in different types of schools. Primary school, secondary school and vocational school highlighted the role of digital facilities and technologies. Colleges and universities promoted innovation in digital teaching training, strengthened teachers' digital skills, and thus improved teaching quality.

- Research on digital education was also to improve. Vocational education works as a key field related to digitization for its industrial leading position. Research on needs of learning models, use of digital technology, and analysis to the impact of digital training on professional workers were encouraged.

- In colleges and universities, the research on higher education digitization was actively promoted, and the construction of information management and decisionmaking were strengthened.

Although Digital Strategy 2014-2017 is a document oriented to economy and an overall development in the German society, it covers a wide range of projects that are important for the development to German digital education. The measures hereby on digital education have become the cornerstone of German educational digitization.

\subsubsection{Setting the goals for digital education construction in "Digital Strategy 2025".}

After Digital Action Agenda 2014-2017 being released, the German Federal Ministry of Economy and Energy issued Digital Strategy 2025 in March 2016, establishing an action plan for digitization from 2016 to 2025. While digital infrastructure and digital security remain components, this strategy focuses on fostering new business models, building smart networks, modernizing production bases, and using digital technologies to boost research and innovation.

In the field of education, the document proposes a series of aims and related measures to be achieved by 2025 . The aims include but are not limited to the following: by 2025 , the construction of German digital education facilities should reach the world's leading level; German primary and secondary school graduates should have basic knowledge of information science, algorithms and programming by 2025; and Germany should become the most attractive country for workers to obtain the latest information and knowledge. As a strategic measure, the Federal Ministry of Education and Research continued to build digital infrastructure for education; it also improved vocational technical standards as well as training guidelines, and encouraged digital vocational education 
services; moreover, STEM disciplines such as big data analysis, industrial software, information security and other related disciplines were encouraged.

It can be said that, as a part of the comprehensive development of German digitization, German digital education measures had gradually formed their own systematic framework. Based on digital equipment and teaching technology, the scope was extended and evolved in more aspects, such as teacher training, capability requirements and disciplines research.

\subsection{The Second Period: Forming the Guideline and Programs for Digital Education Construction, Leveraging Citizens' Digital Capability through Structural Development of Digital Education}

When digitization is no longer limited into an industry or an economic field, but becomes a reform within the whole society, it means that every section needs to form their own digitization structure.

In October 2016, the Federal Ministry of Education and Research issued the document Education Strategy for a Digital Knowledge Society, which put forward the concept of "digital education", formed the guideline of "Digitization in Education World 2030" and launched administrative projects for German digital education; the Conference of Culture Ministers released the document Education in the Digital World in December the same year, which built the framework of theoretical suggestions, including infrastructure, organization building, teacher training, education research, teaching management and legal education.

Since then, the German Federal Ministry of Education formed its own systematic digitization practice plan for the education system, independently from other German systems, providing guidance and benchmark for digital education development, and opening a path to "Education World Digitization 2030".

- Digital Infrastructure should be promoted: It is proposed that digital education infrastructure including hardware equipment, digital teaching media and digital teaching resources should be expanded, such as school facilities, digital teaching content, platform, etc. The use of electronic devices, electronic teaching materials, mobile digital classrooms, virtual laboratories, research databases, digital simulation and other teaching methods should be introduced [5]. Legal support should be provided for teaching materials, teaching data, patents and other contents; It is suggested to promote education institutions equipped with digital devices (broadband interface, server and terminals, etc.), robots, $3 \mathrm{D}$ printers and other equipment.

- Organization construction should be strengthened: the education organization should broaden and strengthen their groups, including management teams, technical teams and education statistic teams. Education in the Digital World puts forward requirements on the technical capability of school administrators; underlines and strengthens the digital construction of educational management system and teaching management system; it highlights the organization of technical support team for digital education hardware in schools; promotes teachers to carry out training, further education and continuing education in terms of digital capability.

- Digital Competency standards are made clear: the standards for teachers' digital competency and learners' digital competency are made clear. The digital competency standards for teachers proposed in Education in the Digital World include: being able to design and develop teaching plans with digital media and tools; reasonable selecting of appropriate teaching materials and procedures; being able to guide students to think critically in the digital world; being able to carry out digitization in own disciplines according to digital knowledge[5]. The corresponding digital competency that learners should acquire through learning includes: digital information searching and evaluating, digital work collaboration, digital producing, information data protection, analytical thinking and reflective thinking in the digital world [5].

- Theoretical research should be encouraged: Universities should develop corresponding digital disciplinary theories. Digital technology and digital teaching methods should be integrated so as to explore digital curriculum and new models of teaching. Curriculum that inspires learners to practice competencies applying digital media and digital tools should be developed. Intelligent teaching study analysis, or online assessment would be a research focus to develop teaching methods and technology; relevant education research project should be promoted, and education policy based on relevant analysis of digital teaching practices should be developed.

- Digital capability should be cultivated in every educational level: Primary and secondary schools held a variety of competitions and activities to promote students' interest in digitization and to encourage them to develop devices or technologies such as microchips. Vocational education institutions set up digital operation equipment and apply digital technology, learners in these schools should be cultivated for competencies of vocational working, self-management, international communication, project-oriented collaboration and awareness of date security as well as critical thinking when facing the media world. Universities should continue to promote the construction of MINT(STEM) disciplines and explore digital courses, digital learning, blended teaching, online assessment, digital teaching management, and constantly improve the quality of digital teaching[5]. Adult education plays an important role in the lifelong 
learning. It is suggested to adopt multiple, flexible, personalized curriculum patterns according to different age group, education foundation and vocational type. For the adults who left schools already, universities offered "Open Universities" online courses.

- A timely legal framework should be set up: Corresponding data protection and patent protection for the data generated in the process of digital education production and use should be timely provided. Digital regulations should be introduced among teachers, students and producers of instructional materials.

- The potential of German digital education for international cooperation should be explored.

It is proposed that German education providers should provide quality-assured digital education services for the international education market, provide mobile convenience for domestic learners to study abroad, and enhance the attractiveness of German education for foreign learners.

\subsection{The Third Period: Carrying out a Range of Policies Responded Quickly in Various Fields, thus Meeting the Challenges of A.I and Job Transformation.}

The development of artificial intelligence technology brought more pressure to Germany's digitalization construction. With High-tech Strategy 2025 and Federal Digital Strategy as the lead, German released a variety of policies oriented to various groups such as primary and secondary school, vocational education institutes, high schools, working talents and social adults, promoting digital construction to all levels of education, all ages and all fields of education.

- More investment in digital education should be offered. In order to promote digitization in the field of education comprehensively and deeply, the Ministry of Education and Research worked together with local states and nongovernmental partners, providing funds for digital construction in primary and secondary schools, vocational schools, colleges and universities, and adult education institutions.

- The Federation and the states have also signed a total of 5 billion Euros over five years [6] to strengthen the digital construction of the internet and online teaching equipment in primary and secondary schools. It also committed 200 million Euros from 2016-2023 in two stages to improve the basic conditions of digitization of hundreds of cross-enterprise vocational education institutions[7]. Universities would invest over 2 billion Euros in digital education for university students. For improving learning conditions and teaching quality, there was an investment of about 2 billion Euros from 2011 to 2020 [7].
- More support in digital education should be provided for teaching staff.

The government expanded the groups of enterprise trainers, vocational school teachers and testers, and promoted the use of digital media in vocational training and continuing education.

The organization of teaching staff for digital disciplines in colleges and universities has been strengthened.

Besides, there were other relevant measures provided to support universities to improve the quality of teacher education.

- Preparatory talent would be given the priority and the construction of information science disciplines would be enhanced.

The federal government would support the development of information professionals. The action plan MINT (2019-2023) would be further promoted to initiate the disciplines improvement such as mathematics, information technology, natural science and technology. The government encouraged the action plan "Learning Factories" to train future-oriented talents for enterprises. Women are encouraged to study STEM disciplines.

- More attention is placed on vocational education and vocational further education.

The Federal Ministry of Education and Research continued to promote the curriculum reform in vocational education, promote digital technology and media in vocational education; supported research on digital competency and qualification requirements. Vocational education platforms were supported.

The federal government attaches great importance to vocational further education: It helped small and medium enterprises to train technical personnel upgrading technical skills and knowledge. Through policies such as Digitization Strategy and Professional Talents Strategy, Germany has accelerated the organization of digitization teams and A.I. technology teams. Digital technology training and advanced study for front-line personnel were provided, industry talents were supported to advanced training about digital production technology and scientific research.

According to $O E C D$, about $35 \%$ of jobs would be completely changed by 2030 [8]. In response to the change of working structure and the need of industrial digitization, the federal government made effort to improve adult education in universities, vocational training centers, adult education centers, enterprises and other institutions.

Moreover, Artificial Intelligence Strategy, Digital Strategy, Professional Talent Strategy, National Continuing Education Strategy and other policies continued to stress the importance of international cooperation, which contributes to attract talents to work and make research in Germany, and also consolidate the position of German vocational education. 


\section{CONCLUSION}

The slow construction progress of digital education in Germany should be ascribed to the work inefficiency of government administration and non-ideal federal cooperation. Still, some of Germany's ideas for developing digital education are worth learning.

- Attach importance to the digital construction of vocational education and training according to the need of economic growth and industrial development.

- Strengthen digital education for preparatory talents, and update the digital competency of the work forces.

- Highlight systematic theoretical research of digital education, enhance curriculum construction of digital teaching and intensify the cultivation of digital competency.

German digital education focuses on future, advocates to promote an overall development and a systematic reform of education with digitization. It attaches importance to the application of digital technology, thus being inclined to vocational education, vocational continuing education and to social adults. It develops digital education on the base of primary and secondary school education, it is led by vocational education, standing on the support of higher education and expanding into the continuing education. The educational departments of German federal government continuously strengthen the digital infrastructure construction, promote the digital transformation in the concept of teaching and research, improve the digital capability of teachers and students and even the whole society. The digital education construction of Germany presents the Characters of industry-leading, openness, systematicness and sustainability.

\section{REFERENCES}

[1] Bundesministerium für Wirtschaft und Energie, Bundesministerium des Innern, Bundesministerium für Verkehr und digitale Infrastruktur. Digitale Agenda 2014-2017[EB/OL].
[2] Bundesministerium für Bildung und Forschung. Bildungsoffensive für die digitale Wissensgesellschaft [EB/OL]. [2016-10-01]. https://www.bmbf.de/files/Bildungsoffensive_fuer_die_ digitale_Wissensgesellschaft.pd

[3] David Kergel, Birte Heidkamp-Kergel. Analysis about Digitization in High School Teaching and Learning in Germany. [J]. Research on Education of Universities of Appliance Science. 2019 (9): 71-75. (In Chinese)

[4] Chen Zheng. Hasso Plattner Institute in Germany launched "open HPI" [J]. World Education Information. 2020(7): 78. (In Chinese)

[5] Kulturministerkonferenz. Bildung in der digitalen Welt[EB/OL].[2016-12- 08]

https://www.kmk.org/fileadmin/Dateien/veroeffentlichu ngen_beschluesse/2016/2016_12_08-Bildung-in-derdigitalen-Welt.pdf

[6] Verwaltungsvereinbarung DigitalPakt Schule 2019 bis 2024 [EB /OL]. [2019-05-16].

https://www.bmbf.de/files/VV_DigitalPaktSchule_Web. pdf

[7] Bundesministerium für Bildung und Forschung. Die Hightech-Strategie 2025.[EB/OL]. [2018-09-05]. https://www.bmbf.de/upload_filestore/pub/Forschung_u nd_Innovation_fuer_die_Menschen.pdf

[8] Bundesministerium für Arbeit und Soziales, Bundesministerium für Bildung und Forschung. Nationale Weiterbildungsstrategie [EB/OL]. [2019-0612].https://www.bmbf.de/files/NWS_Strategiepapier_ba rrierefrei_DE.pdf 